\title{
Ethics Relevance of Interpersonal Communication in Ihya Ulun Al-Din with Islamic Communication
}

\author{
Muttaqien ${ }^{1,3}$, Mohd Hatta ${ }^{2}$, Zainal Arifin' \\ ${ }^{1}$ Ph.D Student in Islamic University of North Sumatera (UINSU), Medan, Indonesia \\ ${ }^{2}$ Islamic University of North Sumatera (UINSU), Medan, Indonesia \\ ${ }^{3}$ Islamic Religion Institute (IAI), Al-Aziziyah Samalanga, Bireuen, Indonesia \\ tgkdrsaiful@gmail.com
}

\begin{abstract}
The purpose of this research were to analyze and relate what was conveyed by AlGhazali about communication and interpersonal through his work which was abandoned by the author 900 years ago with the phenomenon of conventional communication developed by communication experts in the current era with the formulation of the problem namely; First, what is the ethics of Interpersonal communication in the Ulum Al-Din Ihya book by Imam AlGhazali: Second, What is the relevance of the ethics of interpersonal communication in IhyaUlum Al-Din by Imam Al-Ghazali with Islamic communication ethics in the Qur'an, Imam Al-Ghazali's work qualitatively regarding the ethics of interpersonal communication. Primary data sources, namely the main data source of the author is literature by Imam alGhazali, especially in Sufism which focuses on the book IhyaUlum Al-Din. In terms of data collection, the author took a library survey technique and literature study, a library survey that is collecting data in the form of a number of literature. The collected data will be analyzed using the principle of content analysis. Research findings include; 1). Ethics of Interpersonal Communication according to Imam Al-Ghazali in the book IhyaUlum Al-din, consists of ethics messages on interpersonal communication with fellow human beings which includes good oral communication ethics, mutual help and forgiveness of others, have a generous nature. The relevance of Imam Al-Ghazali's communication ethics with Islamic religious communication contained in the Koran, in that context, there are six da'wah communications according to the Qur'an or also called Islamic communication principles.
\end{abstract}

Keywords: ethics; communication; interpersonal

\section{Introduction}

One indication that humans are said to be social beings is because humans always interact with each other. As social beings humans will always want to exchange information, ideas, share experiences, work together with other people to make ends meet. Human and human interaction shows that humans need communication in social life. One of the most dominant types of communication and has a high frequency of occurrence is interpersonal communication or interpersonal communication. ${ }^{1}$

In communicating what we have to understand is the target of communication. We must understand who we are talking to. In communicating, what is equally important is how you can understand who your opponents are communicating with ${ }^{2}$. In communicating we must understand who our opponents are. The goal we communicate in the science of communication is called communicant.

Interpersonal communication is classified into diadik and triadik communication. Diadik communication occurs between two people who are face to face. Triadik is communication that occurs between a communicator and two communicants. Interpersonal

\footnotetext{
${ }^{1}$ Suranto Aw, Komunikasi Interpersonal, (Yogyakarta: Graha Ilmu, 2011), p. 3.

${ }^{2}$ Bustami Narda, Seni Berkomunikasi Dua Arap,(Padang,: Bebe Mustika, 2012), p. 42.
} 
communication is the most effective communication in changing someone's attitudes, behavior and opinions ${ }^{3}$. This communication is dialogic, the communicator can directly know the communicant's response at that time too, if the message delivered is not clear, the communicant is given the opportunity to ask the widest possible question.

The functions of interpersonal communication which include things that are very positive such as to improve human relations human relations, resolve relationships in life, foster good relationships between people and avoid and resolve conflicts. In addition, interpersonal communication also plays an important role to get to know yourself (communicator) and other people (communicants), understand relationships well in the communication process, create and choose good relationships between personal, change lives and behavior and help others in solving problems .

When ethics is associated with communication, ethics is the basis of communication. Ethics provides a moral foundation in building moral conduct for all attitudes and behaviors in communication. Thus, without ethical communication it is unethical. Based on the understanding stated above, I can conclude that the ethics of Islamic communication is a method of communicating in accordance with the standards of moral or moral values in assessing the right or wrong behavior of a person conveyed with Islamic elements directing humans to the benefit of the world and the hereafter.

In the Qur'an it also addresses the problem of communicating by using good sentences and avoiding bad sentences, verses that are affected by these problems include among those in the versez-Zumarayat18:

Meaning: "Who hears the word and follows what is best among them, they are the ones who have been given the instructions and their name, those who have reason. 4 "(QS.Az-Zumar: 18).

Many figures write the concept of communication ethics, but the authors are more interested in reviewing the concept of ethical communication according to Imam Al-Ghazali in the book Ihya Ulum al-ddin related to interpersonal communication the reason the authors are interested in reviewing the concept of communication in the book is to see the reality that happened in the future now, that the ethical value of communication that occurs is quite heartbreaking, for example, as we see in the news of one television station that tells about, a student who reported his teacher to the police because the teacher's actions were deemed excessive and detrimental to his students the teacher overestimates his students, because he is upset with the student's actions. The act of an arbitrary employer, persecuting his servant for making a mistake in carrying out his duties. The actions of children who abandoned their parents, persecuted them, and even had the heart to kill their parents. The actions of parents who should love their children, take care of them, and educate them, but instead engage them, rap them until they are pregnant even until their children give birth

Imam Al-Ghazali in several works explained in detail about interpersonal communication, the author example in the book Ihya Ulumuddin, Al-Ghazali explained in the Muqaddimah of his book that mu'amalah knowledge to draw ourselves closer to God is divided into Dhahirah (which can be witnessed by the five senses ) and Bathinah (which cannot be witnessed by the five senses), while the latter is divided into two parts, namely the

\footnotetext{
${ }^{3}$ Mopammad Spoelpi, Komunikasi Internasional Persfektif Jurnalistik, (Bandung: Simbiosa Rekatama Media, 2009), p.48.

${ }^{4}$ Tim Depag RI, Al-Qur'an dan Tafsirnya, (Jakarta: Departemen Agama RI, 2009), cet.Ke-3, Jilid. 8, p.425.
} 
relationship between humans and other human beings and the relationship of humans as servants with the Creator of Allah SWT. ${ }^{5}$

In connection with the ethics of interpersonal communication, Imam Al-Ghazali in some of his literary works with humanitarian, contemporary, and worldly dimensions offers ethics of interpersonal communication that are effective, contextual and full of wisdom. Part of the ethics of interpersonal communication described by Imam Al-Ghazali in his literary work is communication between parents and children, children and parents, students with teachers, husbands and wives, ethics of communication with neighbors (Jiran), and communication between peers and other interpersonal communication ethics. It's just that the communication ethics intended in this study are those that have moral dimensions and are sourced from holy teachings. In connection with the communication, however, a Muslim must be guided by the main source of Islam, namely the Qur'an and the Sunnah of the Prophet, and all the knowledge of ethics that has been explained by the previous scholars as heirs of the prophets. The author's view, the study of interpersonal communication ethics is relevant and interesting to study in the present conditions, the author will try to analyze and relate what was conveyed by Al-Ghazali about interpersonal communication through his work which was abandoned by the author 900 years ago with the phenomenon of conventional communication developed by communication experts in the current era.

Based on the communication phenomena that occur today and interesting solutions offered by Imam Al-Ghazali in dealing with the problem. Further study of the answers and solutions offered by Imam Al-Ghazali to current issues related to the variety of interpersonal communication and their relevance to Islamic communication in the Koran, the author will analyze these problems, thus this problem becomes a rare and very urgent study to study.

\subsection{Communication Ethics}

\section{Review of Literature}

Ethics comes from Latin, "etthos". Which means morality ${ }^{6}$. The meaning is the sudden behavior with social norms, both ongoing and future. There is an opinion that the word ethics comes from ethos (Greek) which means morality. While the term ethical understanding has been stated by many experts in accordance with different perspectives. For example Ahmad Amin defines ethics as a science that explains good and bad meanings, explains what people should do, states goals that must be addressed by humans in their actions, and shows what should be done. ${ }^{7}$

Ethics relates to four things, as expressed by Abuddin Nata ${ }^{8}$, namely:

a. The deed is the act of being planted in one's soul. Moral deeds are actions performed without thinking. This does not mean that you do everything you do that is unconscious, lost in memory or crazy. When doing the related matters, they remain healthy and conscious.

b. Moral deeds are actions that arise from within the person who teaches them, without any coercion or pressure from outside.

\footnotetext{
${ }^{5}$ Said Mupammad Pusaini Az-zabidi, Ittipaf Sadatul Muttaqin bi Syarpi Ipya Ulumuddin, (Beirut: Darul Fikri, t.t), Jilid. 1, p. 3.

${ }^{6}$ PamzapYa'qub, Etika Pembinaan Akplaul Karimap, (Suatu Pengantar(Bandung:Diponegoro:1990), cet. Ke-4, p.12.

${ }^{7}$ ApmadAmin,Etika(IlmuAkplak)terjemapan,(Jakarta:BulanBintang:1996),cet.Ke-7, p.3.

${ }^{8}$ Abuddin Nata, Akplak Tasawuf..., p.88.
} 
c. Moral deeds are actions that are actually done, not playing games or because of acting.

d. In line with the fourth characteristic, moral conduct is done with the class of words because of Allah, not because people are tested or because they want to get a test.

Thus, the object of discussion of morals relating to norms or examination of things is done by someone. Therefore, even if everything is said to be good or worse, then the size used is a normative measure.

Abuddin Nata assessed that communication ethics seeks to discuss actions carried out by humans that are based on reason and philosophy, which serves to assess, determine, and determine an action done by humans (whether these human actions will be considered good, bad, noble, honorable, etc.) relating to the process of delivering and receiving messages from someone to someone else.

\subsubsection{Deontology Ethics}

Namely emphasizing the obligation of humans to act properly. Three principles must be fulfilled: In order for an action to have a moral value, the action must be carried out based on the obligation. The moral value of the action does not depend on achieving the goal but depends on the goodwill that encourages someone to do it means if the goal achieved, the action is already valued well. As a consequence of these two principles, obligation is a necessary thing from actions taken based on respect for universal moral law.

\subsubsection{Teleology Ethics}

That is measuring the good or bad of an action based on the goal that is to be achieved by the action, or based on the consequences caused by that action. For example, stealing for teleological ethics is not judged good or bad based on the good or bad of the action itself, but by the purpose and effect of the action.

\subsubsection{Selfishness}

Rachels (2004) introduces two concepts related to selfishness. First, psychological selfishness, is a theory that explains that all human actions are motivated by self-serving interests. According to this theory, just people believe there are actions that are noble and sacrificial, but all actions that seem noble and / or sacrificial actions are just an illusion. In fact, everyone only cares about himself. According to this theory, there is no action that is actually altruism, which is an action that cares for others or prioritizes the interests of others at the expense of his interests. Second, ethical egoism is an action based on self-interest. The act of dwelling is characterized by the character of ignoring or harming the interests of others, while acts of selfishness do not always harm the interests of others.

For Muslims that are made big are moral values contained in the Qur'an and the Sunnah of the Prophet, have provided the basic principles that underlie ethics in terms of communication, including:

a. Trustful

The aspect of honesty or objectivity in communication is ethics based on facts. In the Qur'an, this honesty can be termed as a mandate, while the word trust is taken from the word amuna-ya-manu-amanatan which means not to cheat. In the context of ordinary communication it is understood that dishonesty in providing information will cause inner anxiety and loss of a sense of social concern. Q.S. an-Nisa / 4: 58. 
Meaning: "Allah has told you to deliver the message to those who have the right to receive it, and (tell you) if it establishes a law among men so that you can determine justly. Surely Allah gives you the best teaching. Verily, Allah is Hearing, Seeing."9

b. Don't Do Lies (ghair al-kidzb)

While the etymology of the word kidzb is understood as the opposite of the word al-shid (true). In Islam it is highly demanded not to lie because it will bring havoc to other people who receive information. From the point of ethic of communication, lying is a despicable nature. Lies in communication will adjust society because it has absorbed the wrong information. (Q.S. An-Nahal / 16: 116)

Meaning: "And do not say to what your tongue has spoken falsely" This is lawful and this is unlawful, to invent lies against Allah. Surely those who make lies against Allah are not fortunate." 10

c. Fair

As contained in the Qur'an Q.S. Al-An'am / 6: 152.

Meaning: "And do not approach the property of the orphan, except in a more beneficial way, until he is an adult. And complete the measure and scales fairly. We do not burden someone but their ability. And when you say, then you should be just, even though he is a relative (you), and fulfill God's promise. That is what God commands you to remember." 11

From the above verse it is clear that Muslims are instructed to communicate fairly, meaning to communicate correctly, impartially and certainly in accordance with someone's rights. ${ }^{12}$

\subsection{Interpersonal Communication}

\subsubsection{Definition of Interpersonal Communication}

Etymological communication or in its original words comes from Latin, which means communication, which means the same meaning about something. So the ongoing communication process occurs when there are similarities regarding things that are communicated or certain interests. Communication can take place if there is a message to be delivered and there is also feedback from the recipient of the message that can be received directly by the messenger.

Interpersonal communication or interpersonal communication is the process of exchanging information and transfer of understanding between two or more people from a small group of people with various effects and feedback (feedback). ${ }^{13}$

In order for interpersonal communication to be carried out to produce effective interpersonal relationships and cooperation can be improved, we need to be open, trusting, supportive, and open, which encourages attitudes that best understand, appreciate and develop mutual qualities. Interpersonal relations need to be cultivated and improved by improving relations and cooperation between various parties. Interpersonal communication is declared effective if communication meetings are fun for the communicant.

\footnotetext{
${ }^{9}$ Departemen Agama RI, Al-Quran \& Terjemapnya, p.158.

${ }^{10}$ Ibid..., p. 502.

${ }^{11}$ Departemen Agama RI, Al-Quran \& Terjemapnya, p. 271.

${ }^{12}$ Batubara Karim Abdul, Etika Berkomunikasi Anak Kepada Orang Tua DalamPerspektif Islam., http://sumut.kemenag.go.id/ (diakses tanggal 04 Mei 2018)

${ }^{13}$ W. A. Widjaja, Komunikasi dan Pubungan Mayarakat, (Jakarta: Bumi Askara), p. 8.
} 


\subsubsection{Interpersonal Communication Theory}

Interpersonal theories that I will use in this study are theories relating to individuals, individuals and messages, conversation theory and relationship theory.

a. Individual

Each individual must communicate in his life and when someone communicates, then there is one that always happens that is he will see other people or situations that are being faced based on the perspective he has as a messenger (communicator). People or individuals play a very important role in social life, thus it is very understandable for our nagi to begin the discussion of communication theory by studying communicators as individuals. What happens in an individual when he is communicating. ${ }^{14}$

Some important questions that must be answered with regard to intrapersonal communication are regarding "I". Who am I as a communicator ? What abilities do I have to communicate ? What sets me apart from other communicators ? How do other people judge my behavior? How should I adjust from one situation to another ?

Given the importance of the position of individuals in communication, we will first discuss and analyze individuals as communicators. This topic has attracted much attention from experts and theorists since a long time and a number of studies have been conducted for this. According to Stephen Littejohn and Karen Foss in his book Theories of Humam Communication various important communication theories that discuss individuals as communicators see individuals in four topics, namely:

1. What is the nature of the individual

2. How individuals think and know

3. How do individuals perceive themselves (self-concept)

4. How to determine individual identity ${ }^{15}$

b. Individual and Message

The discussion of this theory we begin with an example as follows: Say you want to borrow money from a friend for purposes. The reason you borrow money may not be too important, but you are pretty sure your friend will be willing to lend it. How do you request a loan for this money? You might start thinking about designing the language you will use to choose words and sentences. How will you deliver the message? Nonverbal signs and behaviors that match the words that will be delivered.

In terms of borrowing money from someone, you will do something with your words, not just convey meaning or meaning. In other words, your message has value as an action, exactly a request. There are many ways to borrow money and you prepare a strategy to succeed. You design the message in such a way as to get results, but the results are what you want. Obviously, you need money, but you might also have other goals. You certainly want your friend to keep thinking positively about you, he still feels good when giving his money; not sullen and sincere.

Any speech that focuses attention on aspects of the message. Every individual is a communicator who communicates a message to his interlocutor. How is the structure of a message, how to deliver it, the ethics of delivering messages, symbols and words like what is used, and how the message is interpreted.

Semiotics has an important role in helping us understand how to make messages and how to structure the message. This theory also helps us understand how messages become

\footnotetext{
${ }^{14}$ Morissan, Teori Komunikasi Individu Pingga Massa, (Jakarta:Kencana, 2014), p.65.

${ }^{15}$ Morissan, Teori Komunikasi Individu ..., p. 65.
} 
meaning. If you talk then those who listen to you will pay attention to the words you say, the grammar you use, your tone of voice and movement, as well as eye contact and how you position yourself or your distance to the person you're talking to. This theory recognizes that the meaning you and your listeners give to each of your words and gestures depends on a number of things which are traditions of semiotics, namely: symbol theory, language, nonverbal signs. ${ }^{16}$

c. Conversational Theory

For most people, conversations are normal and routine. Conversation is an ordinary activity, informal in nature and is a form of interaction between individuals that is carried out every day, but in the theory of conversation communication is an important topic that is learned by many communication experts. The conversation is defined as: a set of goals (a sequence of interactions with clear start and end, alternating and having a kind of direction or set of goals). According to Littelejohn and Foss the conversation is controlled by a number of rules, has a structure and shows the existence of unity (coherence) and has meaning. ${ }^{17}$

Conversations cover all forms of interaction between individuals such as chatting with friends, talking between family members, business meetings, talking on the telephone and so on. Given the most dominant conversation in human life, it can be said that conversation is the heart of communication, and because of this reason conversation is an important topic in communication theory.

\section{d. Relationship Theory}

Relations or relatioanship is one of the topics in the science of communication that attracts the most attention because it contains a lot of interesting aspects in it. Relationships are the way two people or two groups feel one another and the way they behave with one another. Relationships are an interesting topic because relationships always change and develop. Various theories of communication really help us understand the differences and changes in a relationship. By using the lens of communication science we will see that relationships consist of patterns of interaction, namely behaviors that mutually respond to a very dynamic nature.

Relationships have become an important topic related to interpersonal communication since the 1960s. Various theories that discuss and explain the relationship that comes from four traditions, namely cybernetics, sociopsychology, sociocultural, and phenomenology. These various theories help us understand relationships in various perspectives. ${ }^{18}$

\section{Research Methodology}

This research includes liberative research with a hermeneutic approach trying to interpret text or events that are still abstract into expressions that are understandable to humans. Hermeneutics is an interpretation method that departs from language analysis and then steps into context analysis, meaning "attract" meaning gained into space and time when the process of understanding and interpretation is carried out. This research was conducted by

\footnotetext{
${ }^{16}$ Morissan, Teori Komunikasi Individu ..., p. 135.

${ }^{17}$ Ibid..., p. 201.

${ }^{18}$ Morissan, Teori Komunikasi Individu ..., p. 284.
} 
Imam al-Ghazali qualitatively regarding the ethics of interpersonal communication. The ethics of interpersonal communication that is explored here is to express the thoughts of Imam al-Ghazali which includes a description of the Ethics of interpersonal communication.

In the operational aspect, this is the opinion of Imam Al-Ghazali which contains the terminology of the ethical aspects of interpersonal communication. Taking into account that is very qualitative, to ensure the quality of data and analysis to be carried out, all aspects of ethics using the interpretation of the principles by looking at the perspective of the clerics interpreting each verse about the ethics of interpersonal communication and then its relevance to the communication aspect.

\section{Discussion}

In that context, there are six da'wah communications according to the Koran, namely the karma qaulan principle (noble words), the sadida qaulan principle (true / straight words), the qaulan ma'rufa principle (good words), the qaulan baligha principle (effective words) / openness), the principle of qaulan layyina (meek words), and the qaulan principle of maisura (proper words). ${ }^{19}$

\section{Qaulan Kariman}

Good communication is not assessed in terms of a person's position or rank. Quite a lot of people who fail to communicate well with others are caused by using words that are wrong and potentially degrading others. Dehumanizing others is like giving a bad image to someone else. This is what makes a bad relationship between someone to others. Because they feel their words are not valued, the other person tends not to continue the conversation and suddenly distances himself with a feeling of disappointment. The senula is happy to the other person, turns to hate only because of words.3 Islam teaches that to use noble words in communicating to anyone. This noble word is like in Q.S. al-Isra / 17: 23.

Meaning: And your Lord has commanded that you do not worship other than him and should do well to your father's mother as well as possible. if one of the two or both of them reaches old age in your care, then do not say to both the words "ah" and do not yell at them and say to them noble words. ${ }^{20}$

\section{Qaulan Sadida}

The Malay proverb says, "One step to the test for the life of an unbeliever." That is, if someone has been caught cheating, people will not believe it anymore. With regard to honesty of communication, the Koran reveals various communication contexts which are conditionally vulnerable to communication deviations. There are two statements (verses) that talk about the truth of the contents of communication, namely QS. An-Nisa / 9: 4 and AlAhzab / 33: 70. The word sadida recitation, as in QS. An-Nisa verse 9.

Meaning: And God fear those who leave behind those who are weak, who are worried about them. therefore let them fear God and let them speak the right words.

\section{3). Qaulan Ma'rufa}

\footnotetext{
${ }^{19}$ Ibid, p. 10.

${ }^{20}$ Departemen Agama RI, Al-Quran \& Terjemapnya, p.531.
} 
The expression qaulan ma'rufa, if traced deeper can be interpreted as "appropriate and good expression or speech". "Deserving" here can also be interpreted as "respectable" words, while "good" is interpreted as "polite" words. ${ }^{21}$ Qaulan Ma'rufa can be translated with an appropriate phrase. The word ma'rufa is in the form of mim'ul isim which originates from his madhafi, a Muslim. One of the etymological meanings of 'maurufa is al-khair or al-ihsan, which means the good ones. So qaulan ma'rufa contains good and proper words or expressions. In the Qur'an the expression qaulan ma'ufuf is found in surah Al-Baqarah, 235, Al-Ahzab; 32, Al-Baqarah; 263, An-Nisaa; 5 and 8. In the Qur'an Q.S. al-Baqarah / 2: 263. Allah says:

Meaning: Good words and forgiveness are better than charity which is accompanied by something painful (the recipient's feelings). Allah is Rich, Most Merciful.

\section{4). Qaulan Baligha}

Qaulan baligha is a phrase contained in the Qur'an. Baligha comes from the word balagha which means up or fashih. In the context of communication, this phrase can be interpreted as effective communication. This understanding is based on the interpretation of the words that have etched on their souls contained in the Qur'an Q. S. al-Nisa / 4: 63.

Meaning: "They are people whom God knows what is in their hearts. Therefore turn away from them, and give them a lesson, and say to them words that have etched on their souls. "22

\section{5). Layulina Qaulan}

Islam teaches to use gentle communication to anyone. In families, parents should communicate to children in a gentle manner, far from violence and hostility. By using gentle communication, in addition to having a friendly feeling that infiltrates the child's heart, he also tries to be a good listener. ${ }^{23}$ The command to use the meek is found in the Qur'an Q.S. Thaha / 20: 44.

Meaning: "Then speak to both of you with meek words, hopefully he remembers or is afraid". ${ }^{24}$

\section{Qaulan Maisura}

In communication, both oral and written, it is recommended to use language that is easy, concise, and precise so that it is easily digested and understood. In the Qur'an the term qaulan maisura is found which is one of the guidelines for communicating using language that is easy to understand and relieve feelings. ${ }^{25}$ For example, in the Qur'an QS. Al-Isra / 17: 28. Meaning: "And if you turn away from them to obtain the mercy from your Lord whom you wish for, then say to them what is appropriate". ${ }^{26}$

\footnotetext{
${ }^{21}$ Wapyu Ilaipi, Komunikasi Dakwap, (Bandung: Remaja Rosda Karya, 2010), p. 183.

${ }^{22}$ Departemen Agama RI, Al-Quran \& Terjemapnya, p. 159.

${ }^{23}$ Ibid

${ }^{24}$ Departemen Agama RI, Al-Quran \& Terjemapnya, p. 594.

${ }^{25}$ Ibid

${ }^{26}$ Departemen Agama RI, Al-Quran \& Terjemapnya, p. 532 .
} 


\section{Conclusion}

Ethics of Interpersonal Communication according to Imam Al-Ghazali in the book Ihya Ulum Al-din, consists of ethics messages on interpersonal communication with fellow human beings which includes good oral communication ethics, mutual help and forgiveness of others, have a generous nature. Imam Al-Ghazali also mentions from the point of view of the communicator and communicant contained in the work of Imam Al-Ghazali as follows

a. Communication Ethics of Students and Teachers

b. Communication Ethics Visit

c. Neighboring communication ethics

\section{References}

Abdillah Muhammad ibn Syauman Ibn Ahmad Ibn Mustafa al-Ramli, al-Khauf min Allah Ta'ala t.tp.: Dar Ibn Qayyim, 1993.

A. Hasjmy, Dustur Dakwah Menurut Alquran, Jakarta: Bulan Bintang, cet. 3, 1994.

A. Sudiarja, dkk., Karya Lengkap Driyarkara: Esai-Esai Filsafat Pemikir YangTerlibat Penuh Dalam Perjuangan Bangsanya, Jakarta: Gramedia Pustaka Utama, 2006.

Kusnawan Ash Shiddiq, Aep, Doa-Doa Sukses for Teens, Bandung: Mizan, 2007

Abi Hamid Al-Ghazali, Bidayatul Hidayah,diterjemahkan oleh Ahmad Fahmi bin Zamzam Al-Banjari, Banjarbaru: Toko Buku Darul Yasin, 2015.

Abi Hamid Al-Ghazali, Minhajul A'bidin Ila Jannati Rabbi Al-A'lamin, Semarang: Darul Ihya, t.t.

Abi Qasim 'Abd al-Karim bin Hawazin al-Qusyayri al-Naisaburiy, h. 308.

Abidin , Jamaluddin,KomunikasidanBahasaDakwah,Jakarta:GemaInsaniPress, 1996.

Abidin, JamaluddinAss,KomunikasidanBahasaDakwah,Jakarta:GemaInsaniPress, 1996.

Abu 'Abdillah Muammad ibn Isma'il al-Bukhari, al-Jami' al-Sahih, Juz 9 Cet. I; t.t. : Dar alTauq al-Najah: 1422.

Abu Abbas Ahmad Zaruq al-Fasi, Qawaid al-Tasawwuf, Mishr: t.p., 1318 H.

Al Ghazali, Ihya Ulumiddin, jilid I, terj. Moh. Zuhri, Semarang :Asy Syifa, 2011.

Al-Ghazali, Mengobati Penyakit Hati terjamah Ihya 'Ulum Ad-Din, dalam Tahdzib al-Akhlaq wa Mu alajat Amradh Al-Qulub, Bandung: Karisma, 2000.

Deddy Mulyana, Ilmu Komunikasi Suatu Pengantar, Bandung: Remaja Rosdakarya, 2001.

Departemen Agama RI, Al-Quran \& Terjemahnya,

Depdiknas, Kamus Besar Bahasa Indonesia, Jakarta: Balai Pustaka,, 2002.

Gud Reacht Hayat Padje, Komunikasi Kontemporer: Strategi, Konsepsi, dan Sejarah, Kupang: Universitas PGRI, 2010Antonius Atoshoki Gea, dkk. .aracter Building III: Relasi Dengan Tuhan, Jakarta: Gramedia, 2004.

Hafied Canggara, Pengantar Ilmu Komunikasi, Jakarta : Raja Grafindo Persada, 2004.W. Lawrence, Neuman,Social Research Methods Qualitative and Quantitatif Approaches, Boston: Allyn and Bacon, 1997.

Hamka, Tafsir Al Azhar, Jilid 11, Jakarta: Pustaka Panjimas, 1982.

Ibnu Rajab al-Hambali, Ibnu Qayyim al-Juziyyah, dan Imam al-Ghazali, Tazkiyatun Nafs, alih bahasa: Imtihan al-Syafi'i, (Cet. XXIX; Solo: Pustaka Arafah, 2013.

Imam Abi Abdullah Muhammad bin Ismail Al-Bukhari, Shahih Al-Bukhari, Riyadh: Maktabah ma`arif, Jilid 2, tt. 
Imam Jalalain, Tafsir Jalalain, Bandung : Sinar Baru Algensindo, 1995.

Imam Qusyairi, al-Risalah al-Qusyairiyah, Ter. Umar Faruq, Jakarta: Pustaka Amani, 2002.

Schacht et.al, The Ensyclopaedia of Islam, London:Luzac \& CO, 1965. Jakarta: Rajawali Press, 1994.

M. Abul Quasem dan Kamil, Etika Al-Ghazali: Etika Majemuk di dalam Islam, terj. J. Mahyudin, Bandung: Pustaka, 1988.

Morissan, Teori Komunikasi Individu Hingga Massa, Jakarta: Kencana, 2014.

Muhammad Fakhruddin al-Razy, Tafsir Fakhru Razy, Beirut: Dar al-Fikr, 1990.

Muhammad Fuad Abdul Baqi, Al-Lu'lu Wal Marjan, Jilid 1, Surabaya: Bina Ilmu, 1996.

Sayyid Muhammad bin Muhammad al-Husaini az-Zubaidi, Ittihafu Sadatil Muttaqin bi Syarhi Ihya Ulum al-din, Beirut Dar Fikr, t.t.

Shoelhi, Mohammad, Komunikasi Internasional Perspektif Jurnalistik, Bandung: Simbiosa Rekatama Media, 2009

Warson Munawwir, Ahmad, Kamus Al-Munawwir, Edisi II, Cet. XXV, Surabaya: Pustaka Progressif, 2002.

Ya'qub, Hamzah Etika Pembinaan Akhlaul Karimah (Suatu Pengantar), Bandung: Diponegoro, 1990.

Yajub, Ismail, Terjamahan Ihya' Al Ghazali, Jakarta: Faizan, 1983.

Yunus, Mahmud, Kamus Arab Indonesia, Jakarta: Yayasan Penyelenggara Penterjemah / Pentafsir Al-Qur'an, 1973. 